Supplement of Atmos. Chem. Phys., 21, 9681-9704, 2021

https://doi.org/10.5194/acp-21-9681-2021-supplement

(c) Author(s) 2021. CC BY 4.0 License.

(c) (1)

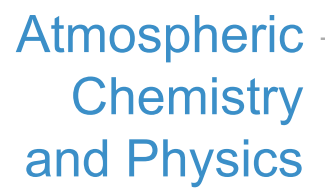

Supplement of

\title{
Highly oxygenated organic molecule (HOM) formation in the isoprene oxidation by $\mathrm{NO}_{3}$ radical
}

Defeng Zhao et al.

Correspondence to: Thomas F. Mentel (t.mentel@fz-juelich.de) and Defeng Zhao (dfzhao@fudan.edu.cn)

The copyright of individual parts of the supplement might differ from the article licence. 
1 In the supplement we describe the derivation of calibration coefficient of $\mathrm{NO}_{3}{ }^{-}-\mathrm{CIMS}$ for $\mathrm{H}_{2} \mathrm{SO}_{4}$. In addition, 2 more tables and figures besides those in the main text are provided. 
In order to convert peak intensity in mass spectra to concentration, the calibration coefficient of $\mathrm{H}_{2} \mathrm{SO}_{4}$ is derived. $\mathrm{H}_{2} \mathrm{SO}_{4}$ was produced in-situ in SAPHIR chamber by the oxidation $\mathrm{SO}_{2}$ by $\mathrm{OH}$. $\mathrm{SO}_{2}(\sim 15 \mathrm{ppb})$ was added into the chamber and the roof was opened to initiate photo-oxidation. In SAPHIR chamber, OH radicals are mainly formed by the photolysis of HONO (nitrous acid) directly coming off the chamber walls through a photolytic process (Rohrer et al., 2005;Zhao et al., 2016). NO ( 20 ppb) was added which can enhance OH production by photochemical recycling. $\mathrm{OH}$ concentration was characterized by using laser induced fluorescence (LIF) with the details described in (Fuchs et al., 2012). $\mathrm{SO}_{2}$ concentrations was characterized using an $\mathrm{SO}_{2}$ analyzer (Thermo Systems 43i).

12 The concentration of $\mathrm{H}_{2} \mathrm{SO}_{4}$ in the chamber can be described by the following equation.

$$
\left.\frac{d\left[\mathrm{H}_{2} \mathrm{SO}_{4}\right]}{d t}=k\left[\mathrm{SO}_{2}\right][\mathrm{OH}]-\left(k_{w l}+k_{d i l}\right)\left[\mathrm{H}_{2} \mathrm{SO}_{4}\right]\right)
$$

where $\left[\mathrm{H}_{2} \mathrm{SO}_{4}\right],\left[\mathrm{SO}_{2}\right],[\mathrm{OH}]$ are the concentration of these species, $\mathrm{k}$ is the rate constant for the reaction of $\mathrm{SO}_{2}$ with $\mathrm{OH}, \mathrm{k}_{\mathrm{wl}}$ is the wall loss rate of $\mathrm{H}_{2} \mathrm{SO}_{4}\left(\sim 6.0 \times 10^{-4} \mathrm{~s}^{-1}\right.$ as characterized for low volatility compounds in our previous publication (Zhao et al., 2018)) and $\mathrm{k}_{\mathrm{dil}}$ is the dilution rate of $\mathrm{H}_{2} \mathrm{SO}_{4}\left(\sim 1 \times 10^{-5} \mathrm{~s}^{-1}\right)$.

$$
\left[\mathrm{H}_{2} \mathrm{SO}_{4}\right]=\mathrm{C} \times \mathrm{I}
$$
where $\mathrm{C}$ is the calibration coefficient of $\mathrm{H}_{2} \mathrm{SO}_{4}$, I is the peak intensity of $\mathrm{H}_{2} \mathrm{SO}_{4}$ determined by normalized peak area of $\mathrm{H}_{2} \mathrm{SO}_{4}$ at time t, i.e., the peak area divided by total signal of mass spectrum (termed as normalized count (nc)).

21 Substituting Eq.2 to Eq. 1, one can get

$$
C \frac{d I}{d t}=k\left[\mathrm{SO}_{2}\right][\mathrm{OH}]-C\left(k_{w l}+k_{d i l}\right) I
$$

Integrating Eq.3, one can get

$$
\mathrm{C}=\frac{k\left[\mathrm{SO}_{2}\right][\mathrm{OH}]}{\frac{I-I_{0}}{t}+\left(k_{w l}+k_{\text {dil }}\right) I}
$$

where $\mathrm{I}_{0}$ is the peak intensity at time zero. $\mathrm{C}$ was determined to be $2.5 \times 10^{10}$ molecules $\mathrm{cm}^{-3} \mathrm{nc}^{-1}$. The second term of denominator in Eq. 4 is much lower the first term and can omitted. The uncertainty of $\mathrm{C}$ was estimated to $-52 \% /+$ $101 \%$ from the uncertainty of $\mathrm{SO}_{2}$ concentration $(\sim 7 \%)$, OH concentration $(\sim 10 \%), \mathrm{I}(\sim 10 \%)$ and $\mathrm{k}(\Delta \operatorname{logk}= \pm 0.3)$ using error propagation, which corresponds to $(1.2-5.0) \times 10^{10}$ molecules $\mathrm{cm}^{-3} \mathrm{nc}^{-1}$. The $\mathrm{C}$ value is generally consistent with the value of $3.7 \times 10^{10}$ molecules $\mathrm{cm}^{-3} \mathrm{nc}^{-1}$ in our previous calibration (Pullinen et al., 2020).

HOM yield was calculated as

$$
Y=\frac{[H O M]}{[V O C]_{r}}=\frac{I(H O M) C}{[V O C]_{r}}
$$

where $[\mathrm{HOM}]$ is concentration of HOM and $[\mathrm{VOC}]_{\mathrm{r}}$ is the concentration of VOC reacted. The uncertainty of HOM yield was estimated to $-55 \% /+103 \%$ from the uncertainty of HOM intensity $(\sim 10 \%)$, VOC concentration $(\sim 15 \%)$ and $\mathrm{C}$ using error propagation. 


\section{S2 Detailed mechanisms of trimer formation}

The $\mathrm{C}_{15} \mathrm{H}_{25} \mathrm{~N}_{5} \mathrm{O}_{\mathrm{n}}$ series can be formed by the following reactions:

The $\mathrm{C}_{10} \mathrm{H}_{18} \mathrm{~N}_{3} \mathrm{O}_{\mathrm{n}}(\mathrm{n}=14-20)$ and $\mathrm{C}_{10} \mathrm{H}_{17} \mathrm{~N}_{4} \mathrm{O}_{\mathrm{n}}$ can be formed by the dimers with $\mathrm{NO}_{3}$.

$$
\mathrm{C}_{10} \mathrm{H}_{17} \mathrm{~N}_{3} \mathrm{O}_{\mathrm{n}}+\mathrm{NO}_{3}+\mathrm{O}_{2} \rightarrow \mathrm{C}_{10} \mathrm{H}_{17} \mathrm{~N}_{4} \mathrm{O}_{\mathrm{n}}
$$

RS5

$\mathrm{R} 21$ is likely to be unimportant because both the abundance of $\mathrm{C}_{10} \mathrm{H}_{18} \mathrm{~N}_{3} \mathrm{O}_{n}$ and $\mathrm{C}_{5} \mathrm{H}_{7} \mathrm{~N}_{2} \mathrm{O}_{n}$ were low. Since the peaks of $\mathrm{C}_{10} \mathrm{H}_{18} \mathrm{~N}_{3} \mathrm{O}_{n}(\mathrm{n}=14-20)$ series overlap with $\mathrm{C}_{10} \mathrm{H}_{16} \mathrm{~N}_{2} \mathrm{O}_{n}$, we can only assign them with low confidence.

Similarly, $\mathrm{C}_{10} \mathrm{H}_{17} \mathrm{~N}_{4} \mathrm{O}_{n}$ series overlap with $\mathrm{C}_{10} \mathrm{H}_{15} \mathrm{~N}_{3} \mathrm{O}_{n}$ series (dimer 5).

The $\mathrm{C}_{15} \mathrm{H}_{25} \mathrm{~N}_{3} \mathrm{O}_{\mathrm{n}}$ series can be formed by the following reactions:

$$
\mathrm{C}_{10} \mathrm{H}_{17} \mathrm{~N}_{2} \mathrm{O}_{\mathrm{n} 1} \bullet+\mathrm{C}_{5} \mathrm{H}_{8} \mathrm{NO}_{\mathrm{n} 2} \cdot \rightarrow \mathrm{C}_{15} \mathrm{H}_{25} \mathrm{~N}_{3} \mathrm{O}_{\mathrm{n} 1+\mathrm{n} 2-2}+\mathrm{O}_{2}
$$

The $\mathrm{C}_{15} \mathrm{H}_{26} \mathrm{~N}_{4} \mathrm{O}_{\mathrm{n}}$ series can be formed by the following reactions:

$$
\begin{aligned}
& \mathrm{C}_{10} \mathrm{H}_{17} \mathrm{~N}_{2} \mathrm{O}_{\mathrm{n} 1} \bullet+\mathrm{C}_{5} \mathrm{H}_{9} \mathrm{~N}_{2} \mathrm{O}_{\mathrm{n} 2} \bullet \rightarrow \mathrm{C}_{15} \mathrm{H}_{26} \mathrm{~N}_{4} \mathrm{O}_{\mathrm{n} 1+\mathrm{n} 2-2}+\mathrm{O}_{2} \\
& \mathrm{C}_{10} \mathrm{H}_{18} \mathrm{~N}_{3} \mathrm{O}_{\mathrm{n} 1} \bullet+\mathrm{C}_{5} \mathrm{H}_{8} \mathrm{NO}_{\mathrm{n} 2} \bullet \rightarrow \mathrm{C}_{15} \mathrm{H}_{26} \mathrm{~N}_{4} \mathrm{O}_{\mathrm{n} 1+\mathrm{n} 2-2}+\mathrm{O}_{2} \\
& \mathrm{C}_{10} \mathrm{H}_{16} \mathrm{~N}_{3} \mathrm{O}_{\mathrm{n} 1} \bullet+\mathrm{C}_{5} \mathrm{H}_{10} \mathrm{NO}_{\mathrm{n} 2} \bullet \rightarrow \mathrm{C}_{15} \mathrm{H}_{26} \mathrm{~N}_{4} \mathrm{O}_{\mathrm{n} 1+\mathrm{n} 2-2}+\mathrm{O}_{2}
\end{aligned}
$$

R28 is likely to be unimportant because both the abundance of $\mathrm{C}_{10} \mathrm{H}_{16} \mathrm{~N}_{3} \mathrm{O}_{\mathrm{n}}$ and $\mathrm{C}_{5} \mathrm{H}_{10} \mathrm{NO}_{\mathrm{n}}$ were low.

The $\mathrm{C}_{15} \mathrm{H}_{24} \mathrm{~N}_{2} \mathrm{O}_{\mathrm{n}}$ series can be formed by the following reactions:

$$
\mathrm{C}_{10} \mathrm{H}_{16} \mathrm{NO}_{\mathrm{n} 1} \bullet+\mathrm{C}_{5} \mathrm{H}_{8} \mathrm{NO}_{\mathrm{n} 2} \bullet \rightarrow \mathrm{C}_{15} \mathrm{H}_{24} \mathrm{~N}_{2} \mathrm{O}_{\mathrm{n} 1+\mathrm{n} 2-2}+\mathrm{O}_{2}
$$


60 Fuchs, H., Dorn, H. P., Bachner, M., Bohn, B., Brauers, T., Gomm, S., Hofzumahaus, A., Holland, F., Nehr, S., Rohrer, F., Tillmann, R., 61 and Wahner, A.: Comparison of $\mathrm{OH}$ concentration measurements by DOAS and LIF during SAPHIR chamber experiments at high OH 62 reactivity and low NO concentration, Atmos. Meas. Tech., 5, 1611-1626, 10.5194/amt-5-1611-2012, 2012.

63 Pullinen, I., Schmitt, S., Kang, S., Sarrafzadeh, M., Schlag, P., Andres, S., Kleist, E., Mentel, T. F., Rohrer, F., Springer, M., Tillmann, R., 64 Wildt, J., Wu, C., Zhao, D., Wahner, A., and Kiendler-Scharr, A.: Impact of NOx on secondary organic aerosol (SOA) formation from $\alpha-$ 65 pinene and $\beta$-pinene photo-oxidation: the role of highly oxygenated organic nitrates, Atmos. Chem. Phys. Discuss., 2020, 1-40, 10.5194/acp$66 \quad 2019-1168,2020$.

67 Rohrer, F., Bohn, B., Brauers, T., Bruning, D., Johnen, F. J., Wahner, A., and Kleffmann, J.: Characterisation of the photolytic HONO68 source in the atmosphere simulation chamber SAPHIR, Atmos. Chem. Phys., 5, 2189-2201, 2005.

69 Zhao, D. F., Buchholz, A., Kortner, B., Schlag, P., Rubach, F., Fuchs, H., Kiendler-Scharr, A., Tillmann, R., Wahner, A., Watne, Å. K., 70 Hallquist, M., Flores, J. M., Rudich, Y., Kristensen, K., Hansen, A. M. K., Glasius, M., Kourtchev, I., Kalberer, M., and Mentel, T. F.: Cloud 71 condensation nuclei activity, droplet growth kinetics, and hygroscopicity of biogenic and anthropogenic secondary organic aerosol (SOA),

72 Atmos. Chem. Phys., 16, 1105-1121, 10.5194/acp-16-1105-2016, 2016.

73 Zhao, D. F., Schmitt, S. H., Wang, M. J., Acir, I. H., Tillmann, R., Tan, Z. F., Novelli, A., Fuchs, H., Pullinen, I., Wegener, R., Rohrer, F., 74 Wildt, J., Kiendler-Scharr, A., Wahner, A., and Mentel, T. F.: Effects of NOx and SO2 on the secondary organic aerosol formation from photooxidation of alpha-pinene and limonene, Atmos. Chem. Phys., 18, 1611-1628, 10.5194/acp-18-1611-2018, 2018. 


\section{Supplement figures and tables}

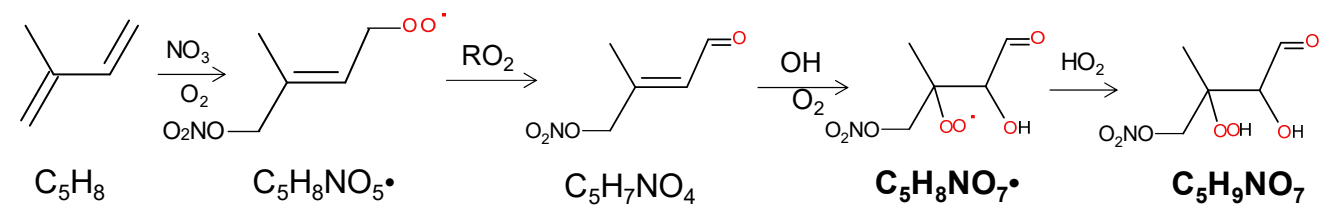

(a)

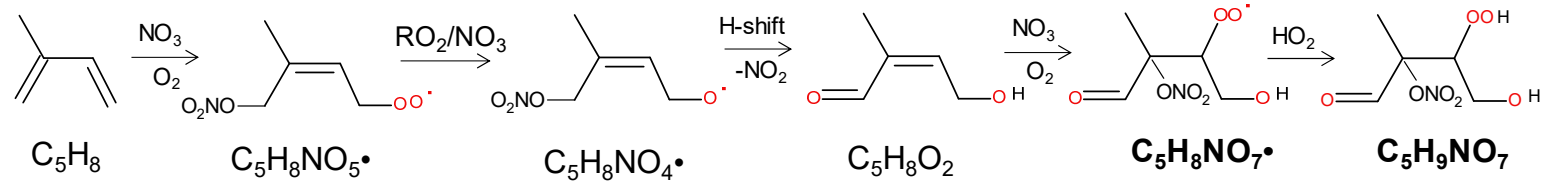

(b)

Scheme S1. The example pathway to form second-generation $\mathrm{C}_{5} \mathrm{H}_{9} \mathrm{NO}_{7}$

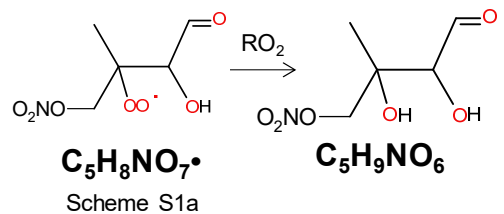

(a)

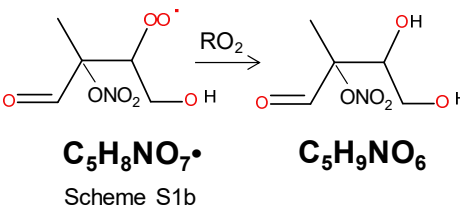

(b)

Scheme S2. The example pathway to form second-generation $\mathrm{C}_{5} \mathrm{H}_{9} \mathrm{NO}_{6}$.

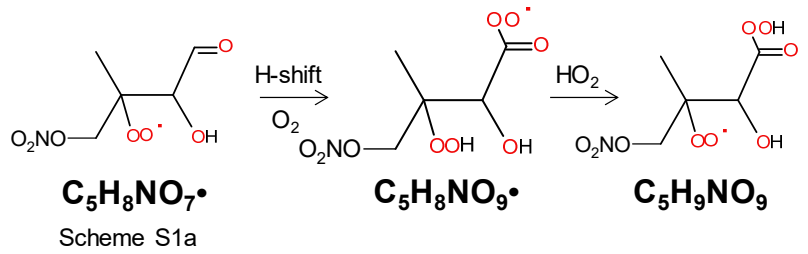

(a)

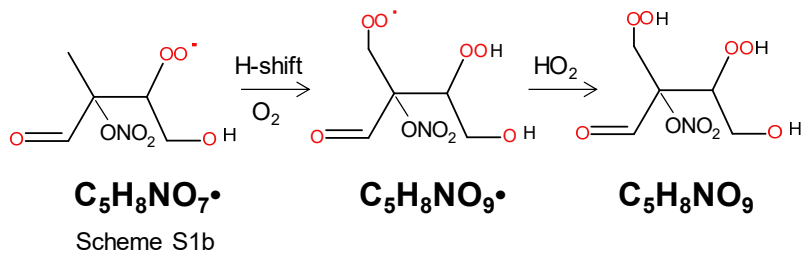

(b)

Scheme S3. The example pathway to form second-generation $\mathrm{C}_{5} \mathrm{H}_{9} \mathrm{NO}_{9}$. 


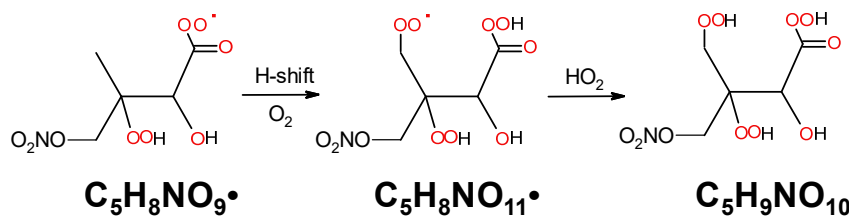

Scheme 53 a

(a)

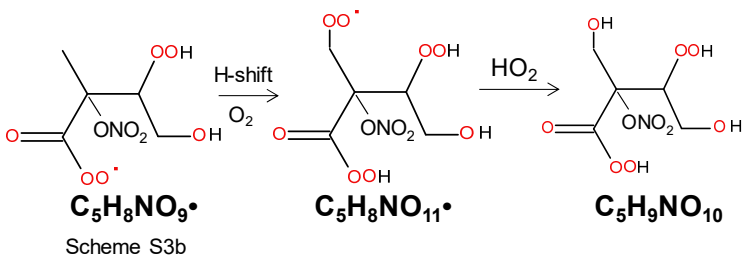

(b)

Scheme S4. The example pathway to form second-generation $\mathrm{C}_{5} \mathrm{H}_{9} \mathrm{NO}_{10}$ 


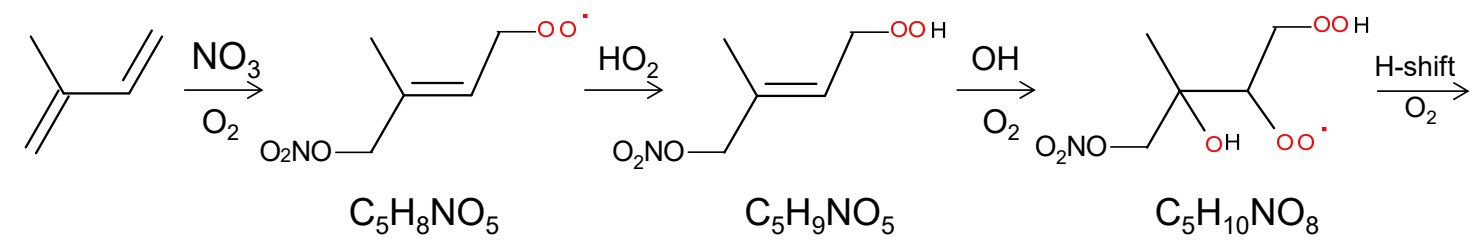

(a)

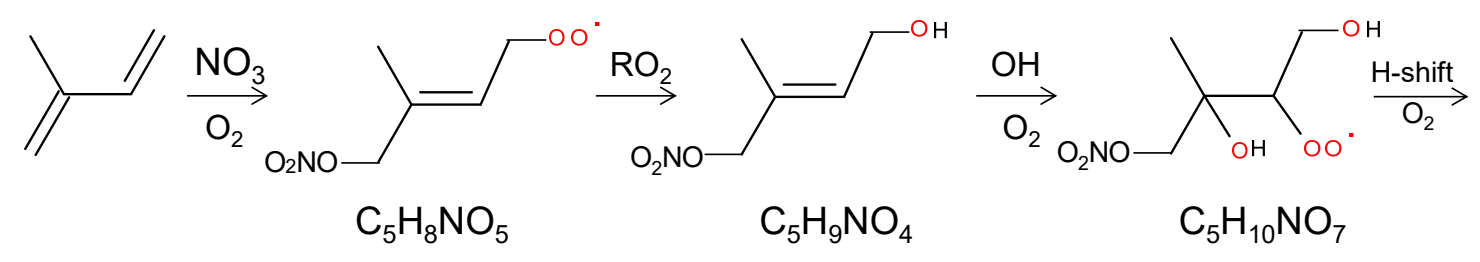

(b)

Scheme S5. The pathway to form $\mathrm{C}_{5} \mathrm{H}_{10} \mathrm{NO}_{\mathrm{n}(\mathrm{n} \geq 7)} \bullet \mathrm{RO}_{2}$ series with even (a) and odd (b) number of oxygen atoms. 


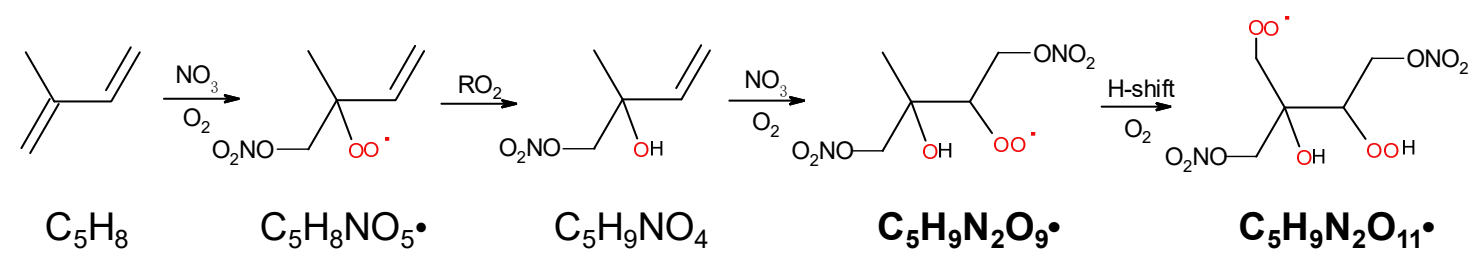

(a)

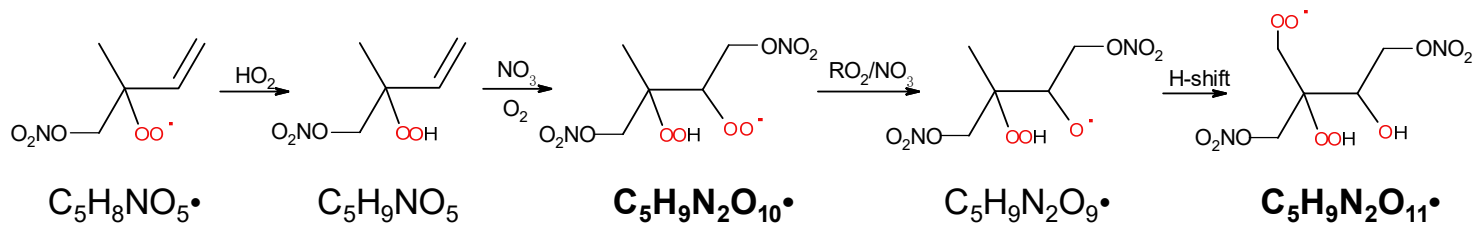

(b)

Scheme S6. The example pathway to form $\mathrm{C}_{5} \mathrm{H}_{9} \mathrm{~N}_{2} \mathrm{O}_{n}(\mathrm{n}=9,11) \mathrm{HOM} \mathrm{RO}_{2}$ series via 1- $\mathrm{NO}_{3}$-isoprene2-OO $\mathrm{RO}_{2}$ by $\mathrm{RO}_{2}$ channel (a) and alkoxy-peroxy channel. The detected products are in bold. 


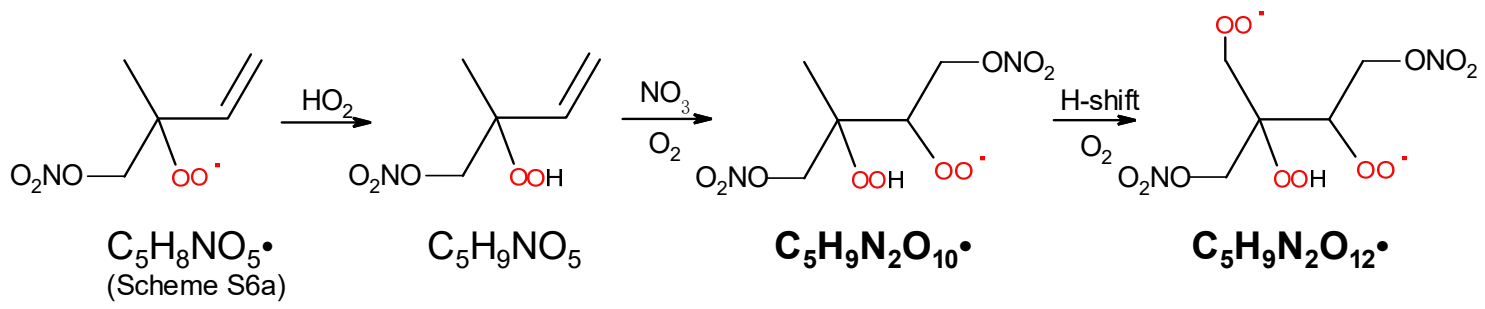

(a)

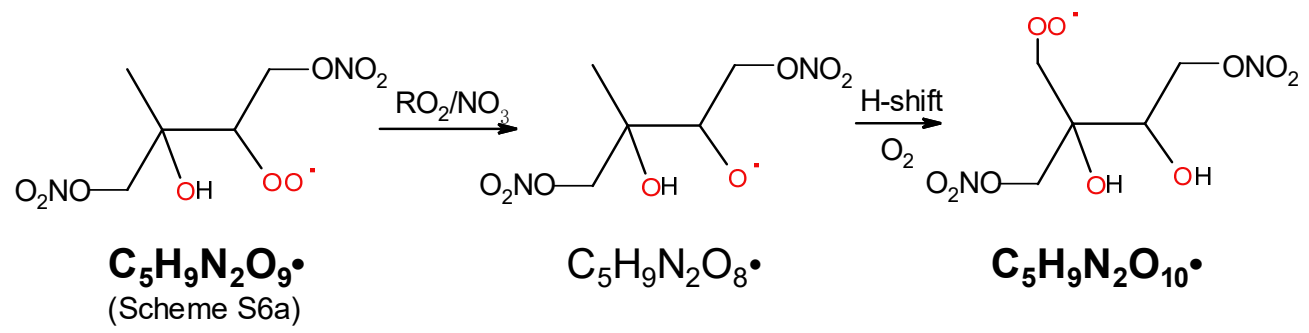

(b)

Scheme $\mathrm{S} 7$. The example pathway to form $\mathrm{C}_{5} \mathrm{H}_{9} \mathrm{~N}_{2} \mathrm{O}_{\mathrm{n}}(\mathrm{n}=8,10,12) \mathrm{HOM} \mathrm{RO}_{2}$ series via 1- $\mathrm{NO}_{3}$ isoprene-2-OO $\mathrm{RO}_{2}$ by $\mathrm{RO}_{2}$ channel (a) and alkoxy-peroxy channel. The detected products are in bold. 


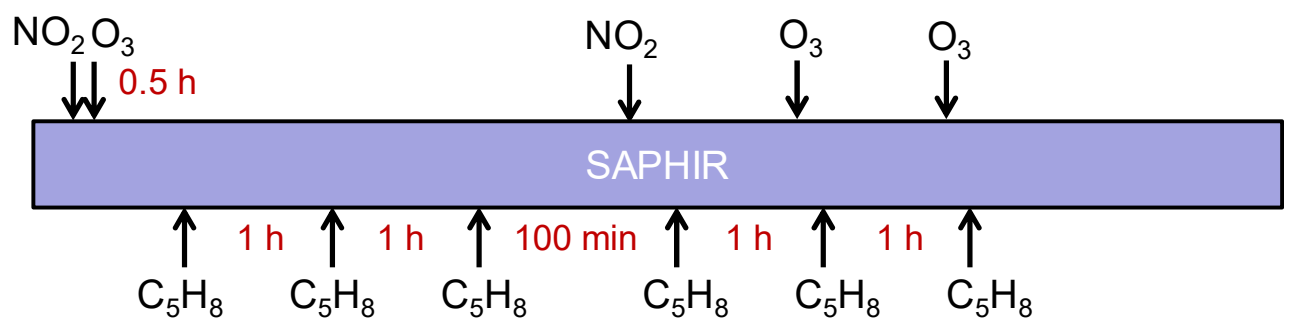

Figure S1. Schematic of the experimental procedure. 


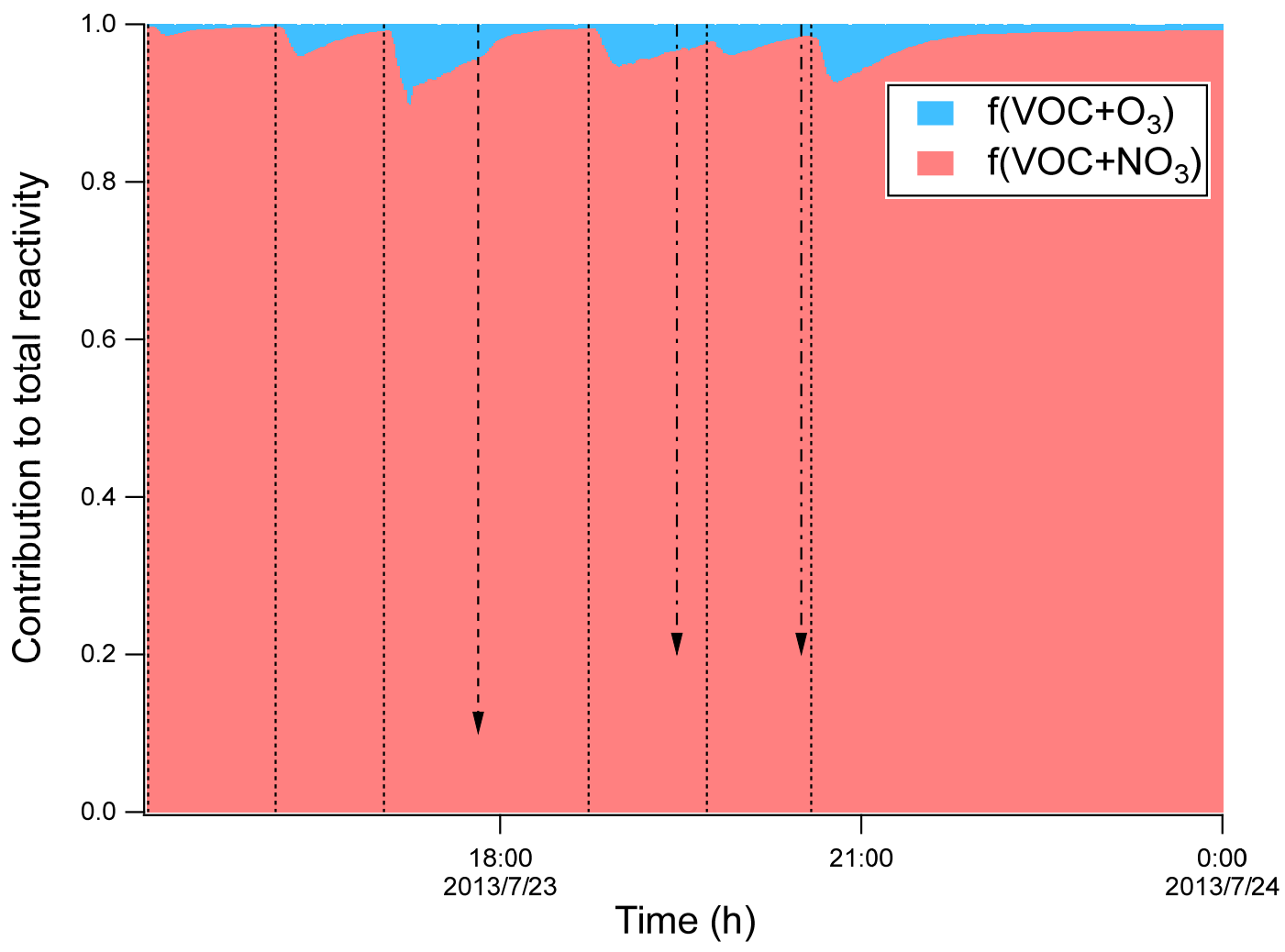

Figure S2. Relative contributions of the reaction rates of isoprene with $\mathrm{NO}_{3}$ and with $\mathrm{O}_{3}$ to the total isoprene loss. The dashed lines indicate the time of isoprene additions. The long-dashed arrow indicates the time of $\mathrm{NO}_{2}$ addition. The dash-dotted arrows indicate the time of $\mathrm{O}_{3}$ additions. 


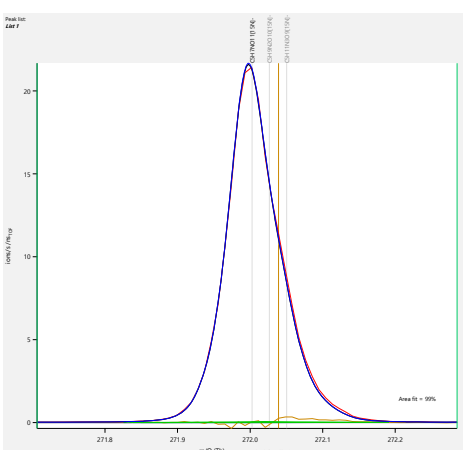

(a)

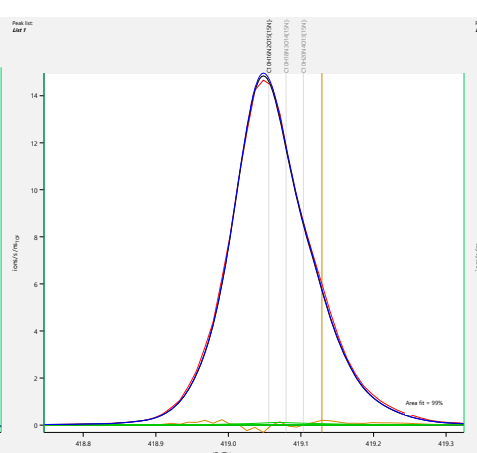

(b)

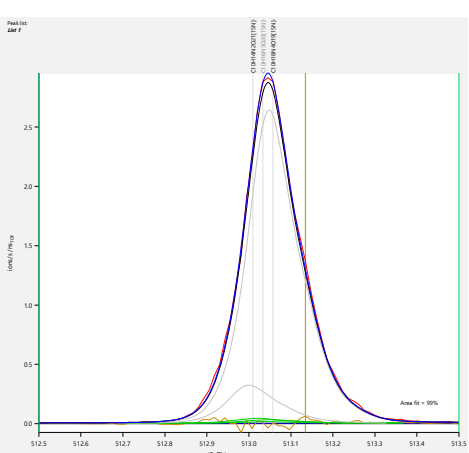

(c)

Figure S3. Examples of peak fitting. Formula in grey indicate compounds that have no noticeable effect on fitting residues and thus not included in the peak list. 


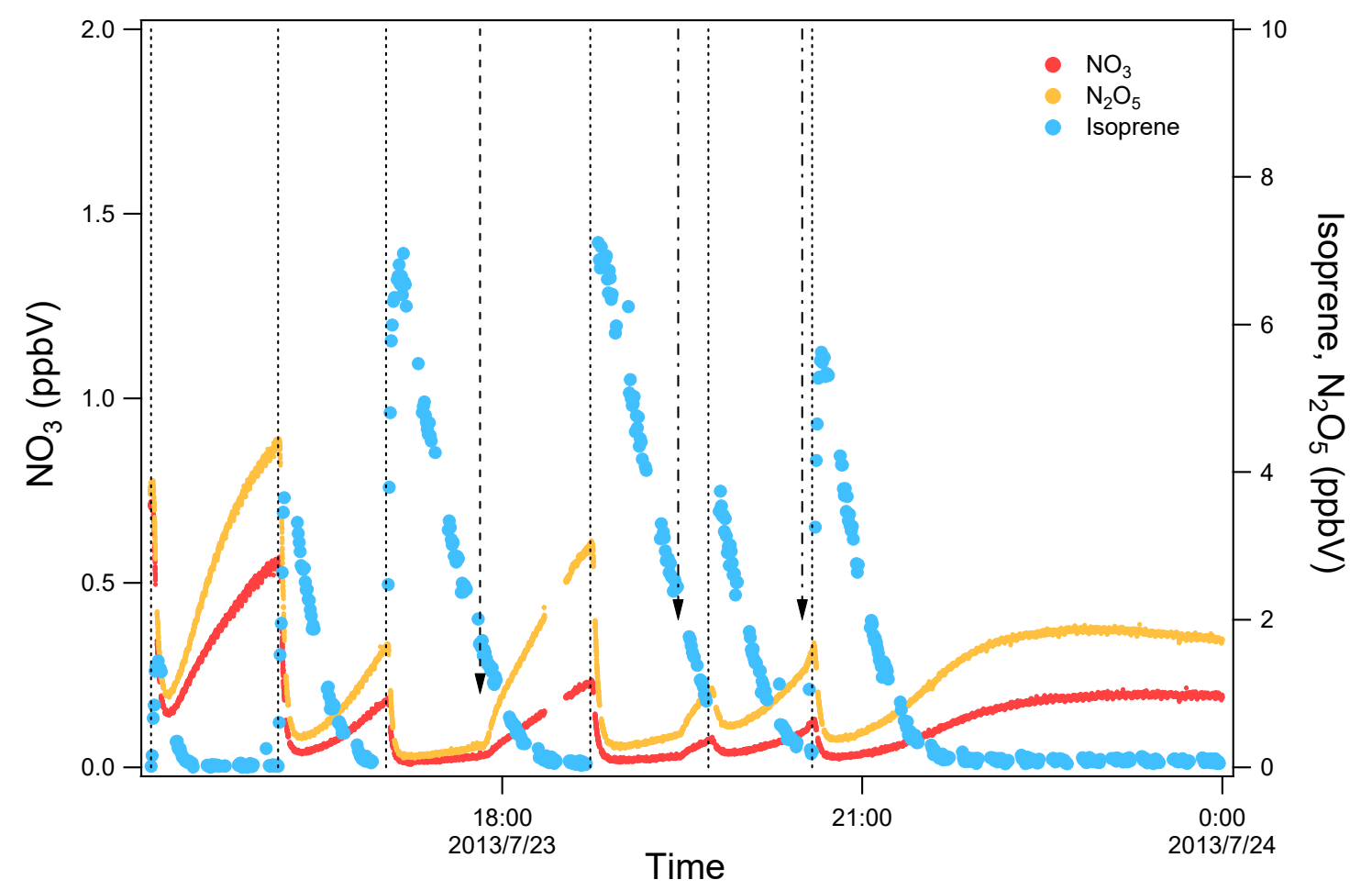

Figure S4. Time series of the of isoprene, $\mathrm{NO}_{3}$, and $\mathrm{N}_{2} \mathrm{O}_{5}$ concentration. The dashed lines indicate the time of isoprene additions. The long-dashed arrow indicates the time of $\mathrm{NO}_{2}$ addition. The dashdotted arrows indicate the time of $\mathrm{O}_{3}$ additions. 


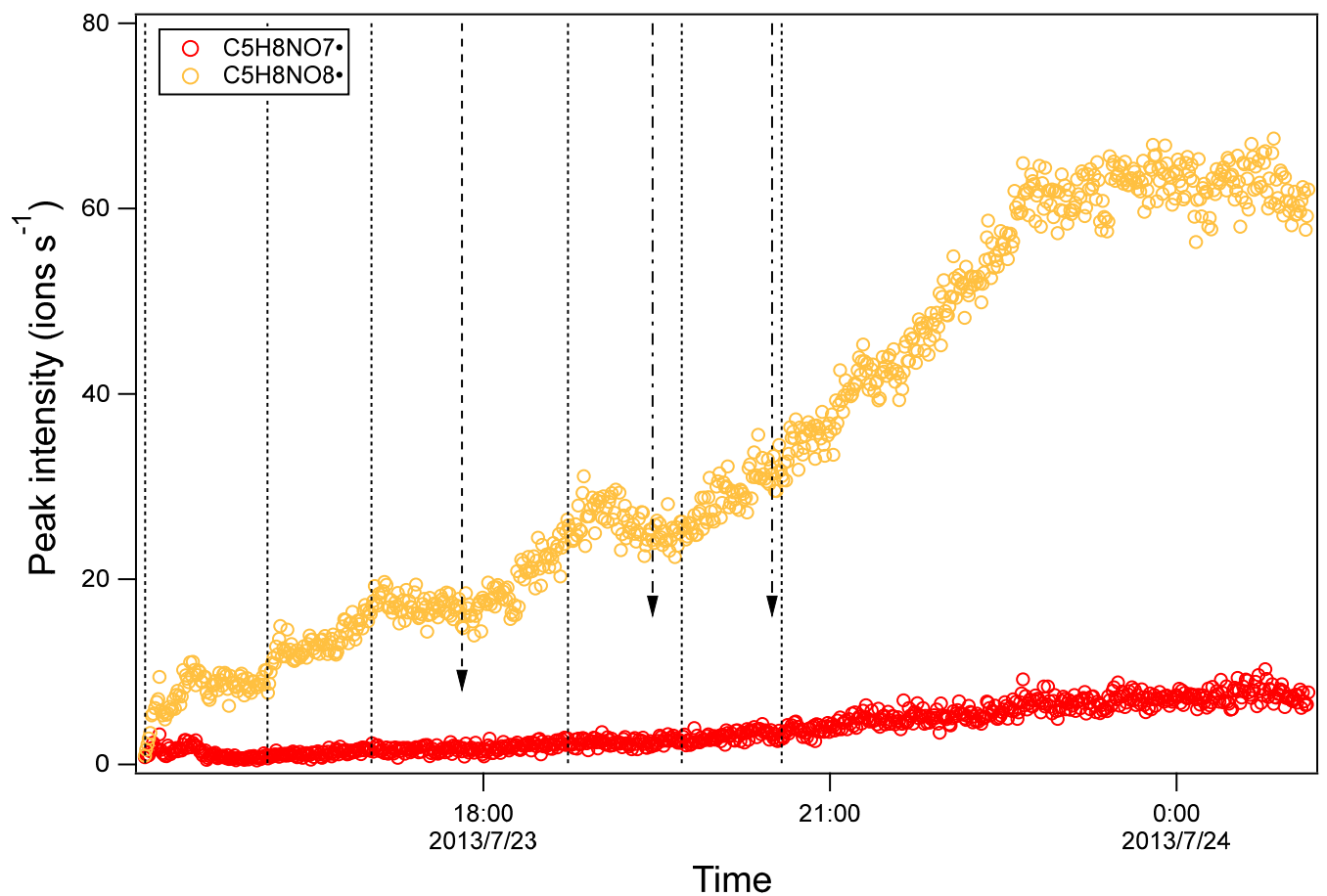

Figure S5. Time series of peak intensity of several HOM monomers of the $\mathrm{C}_{5} \mathrm{H}_{8} \mathrm{NO}_{n} \bullet$ series. The dashed lines indicate the time of isoprene additions. The long-dashed arrow indicates the time of $\mathrm{NO}_{2}$ addition. The dash-dotted arrows indicate the time of $\mathrm{O}_{3}$ additions. 


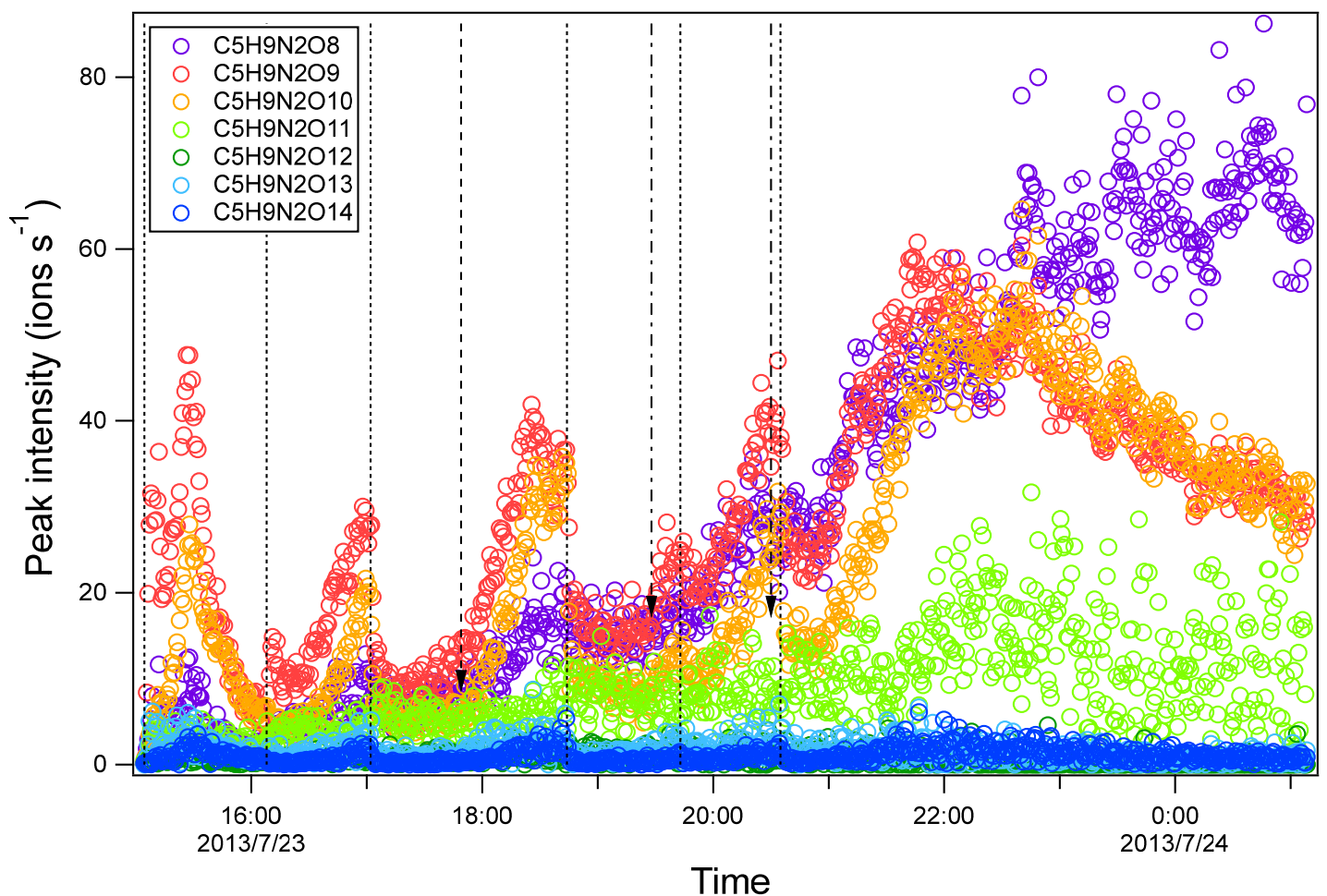

Figure S6. Time series of peak intensity of HOM monomers of the $\mathrm{C}_{5} \mathrm{H}_{9} \mathrm{~N}_{2} \mathrm{O}_{n} \bullet$ series. The dashed lines indicate the time of isoprene additions. The long-dashed arrow indicates the time of $\mathrm{NO}_{2}$ addition. The dash-dotted arrows indicate the time of $\mathrm{O}_{3}$ additions. 


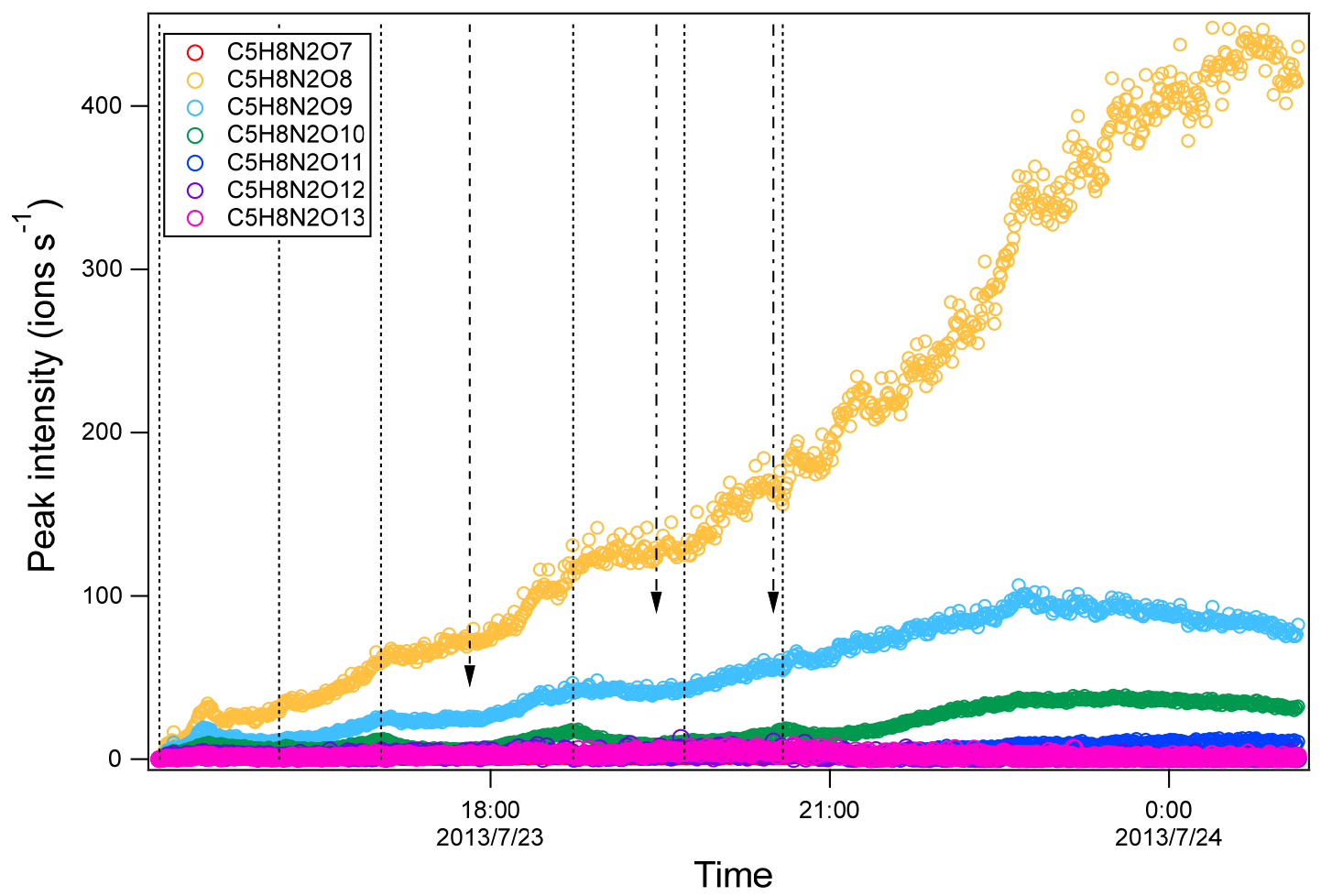

Figure S7. Time series of peak intensity of several HOM monomers of the $\mathrm{C}_{5} \mathrm{H}_{8} \mathrm{~N}_{2} \mathrm{O}_{n}$ series (termination products of $\mathrm{RO}_{2} \mathrm{C}_{5} \mathrm{H}_{9} \mathrm{~N}_{2} \mathrm{O}_{\mathrm{n}}$ ). The dashed lines indicate the time of isoprene additions. The long-dashed arrow indicates the time of $\mathrm{NO}_{2}$ addition. The dash-dotted arrows indicate the time of $\mathrm{O}_{3}$ additions. 


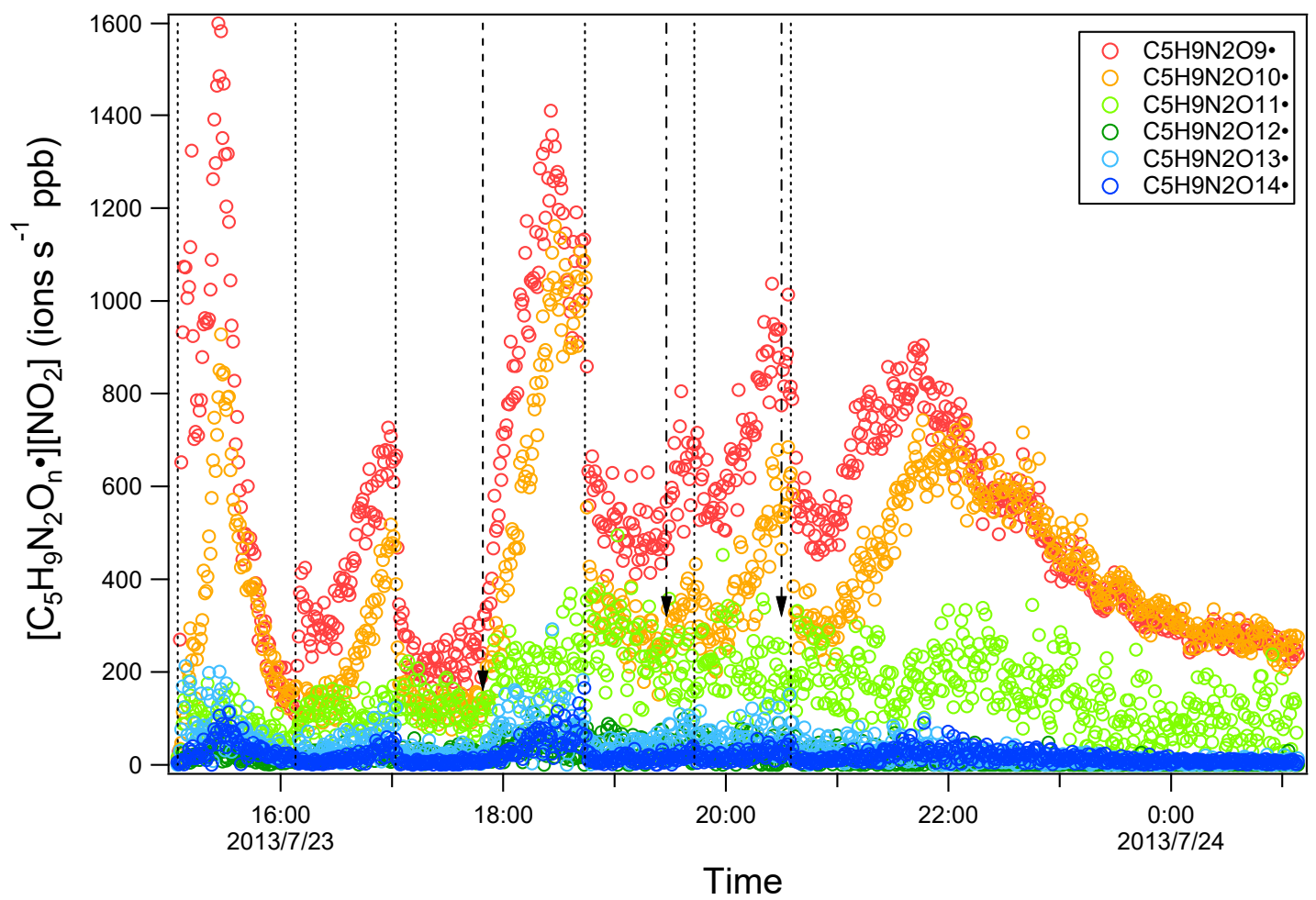

Figure S8. Time series of the product of the peak intensity of $\mathrm{C}_{5} \mathrm{H}_{9} \mathrm{~N}_{2} \mathrm{O}_{n} \bullet$ and $\mathrm{NO}_{2}$ concentration. The dashed lines indicate the time of isoprene additions. The long-dashed arrow indicates the time of $\mathrm{NO}_{2}$ addition. The dash-dotted arrows indicate the time of $\mathrm{O}_{3}$ additions. 


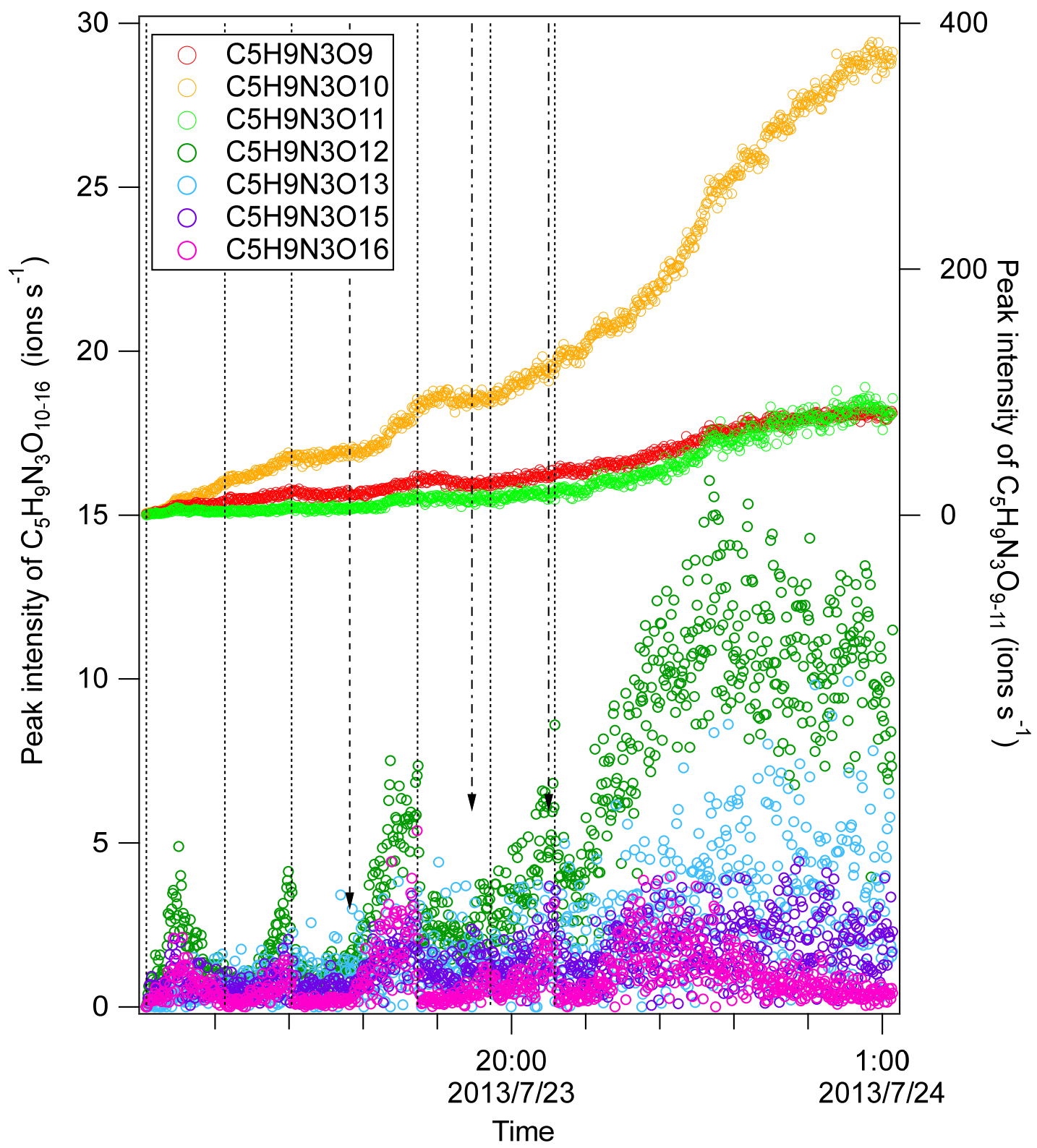

Figure S9. Time series of peak intensity of HOM monomers of the $\mathrm{C}_{5} \mathrm{H}_{9} \mathrm{~N}_{3} \mathrm{O}_{n}$ series. The peak intensity of is shown on the left axis except for $\mathrm{C}_{5} \mathrm{H}_{9} \mathrm{~N}_{3} \mathrm{O}_{10}$. The dashed lines indicate the time of isoprene additions. The long-dashed arrow indicates the time of $\mathrm{NO}_{2}$ addition. The dash-dotted arrows indicate the time of $\mathrm{O}_{3}$ additions. 


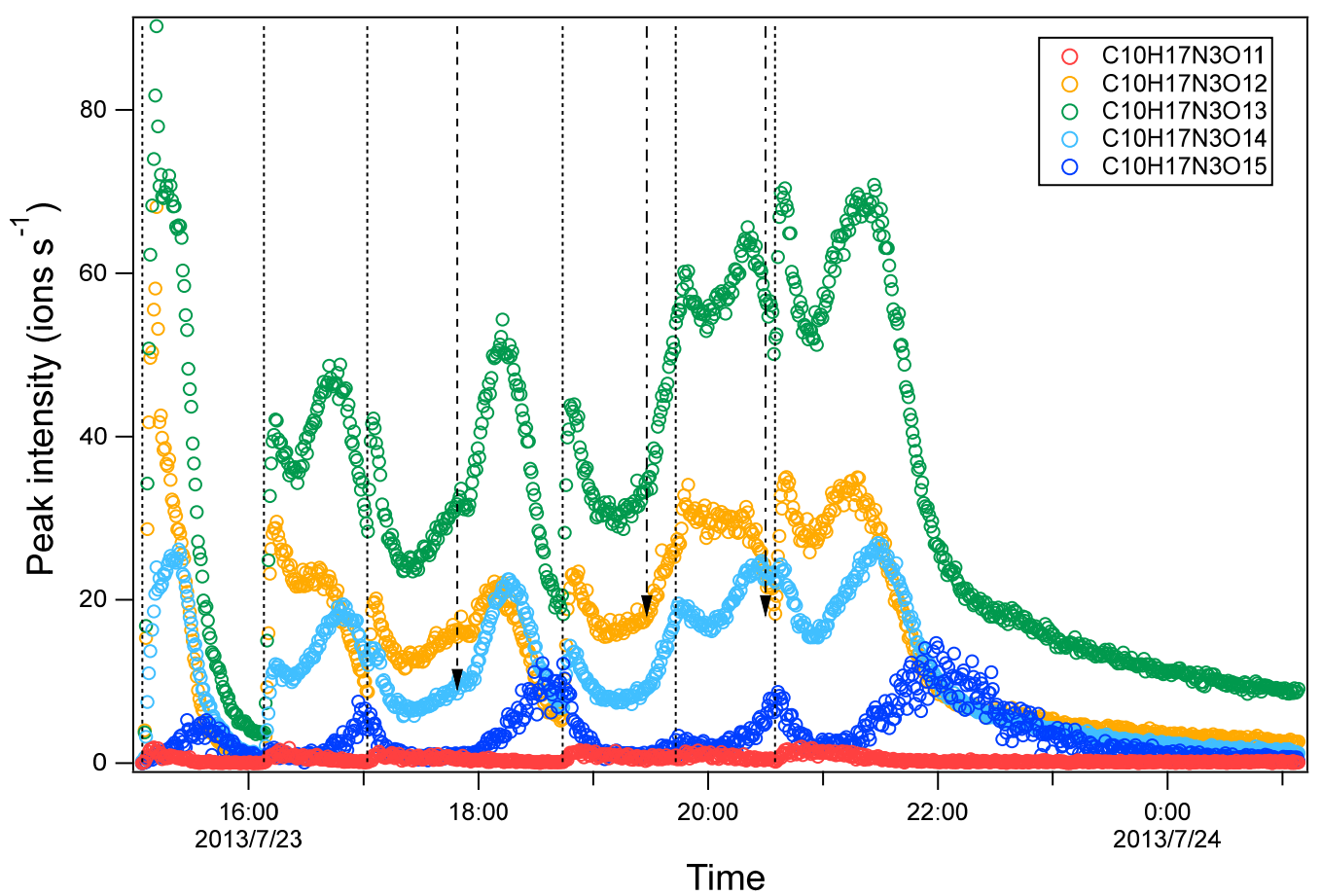

(a)

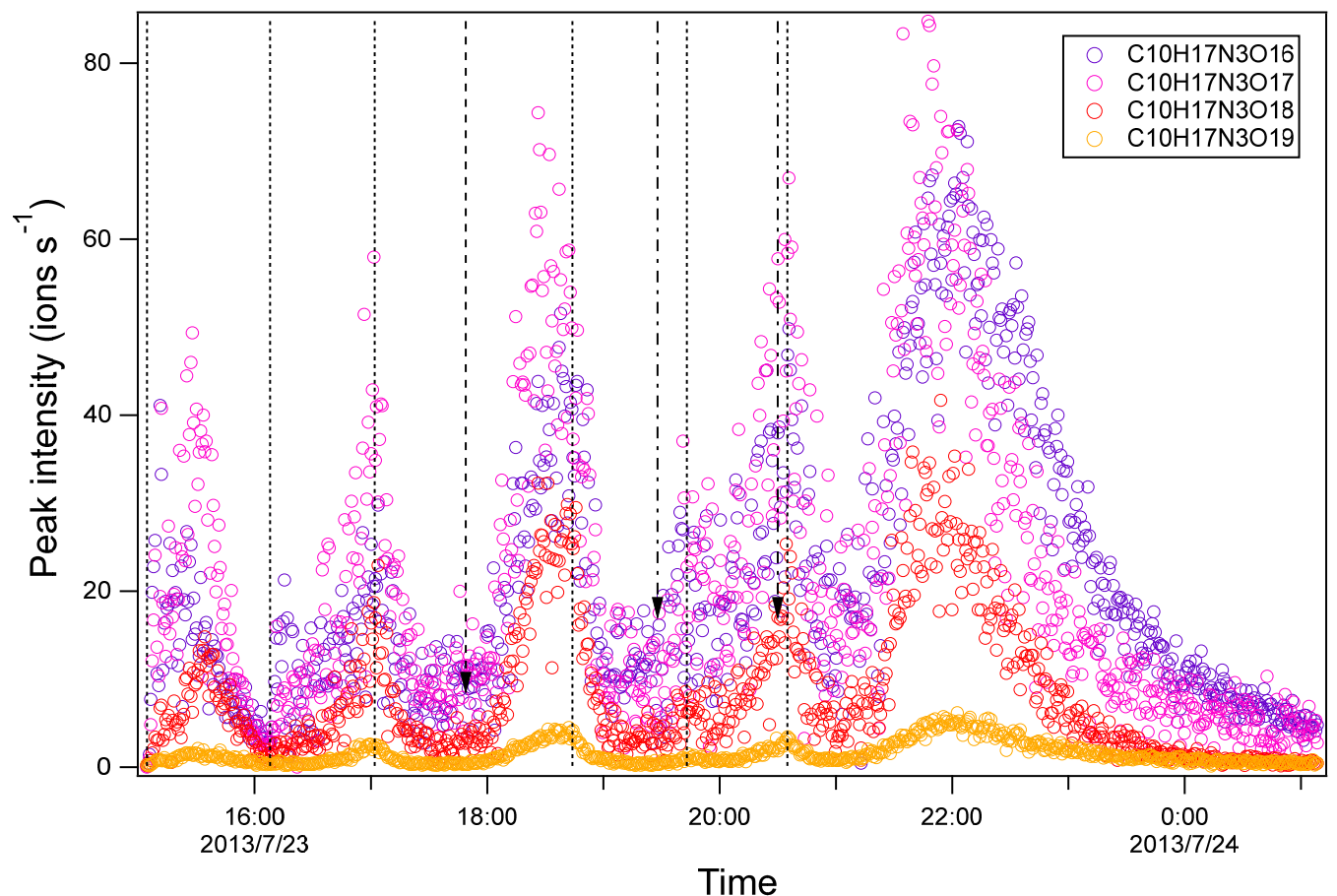

(b)

Figure S10. Time series of peak intensity of several HOM dimers of the $\mathrm{C}_{10} \mathrm{H}_{17} \mathrm{~N}_{3} \mathrm{O}_{n}$ series for $\mathrm{n}=11$ 15(a) and 16-19 (b). The dashed lines indicate the time of isoprene additions. The long-dashed arrow indicates the time of $\mathrm{NO}_{2}$ addition. The dash-dotted arrows indicate the time of $\mathrm{O}_{3}$ additions. 


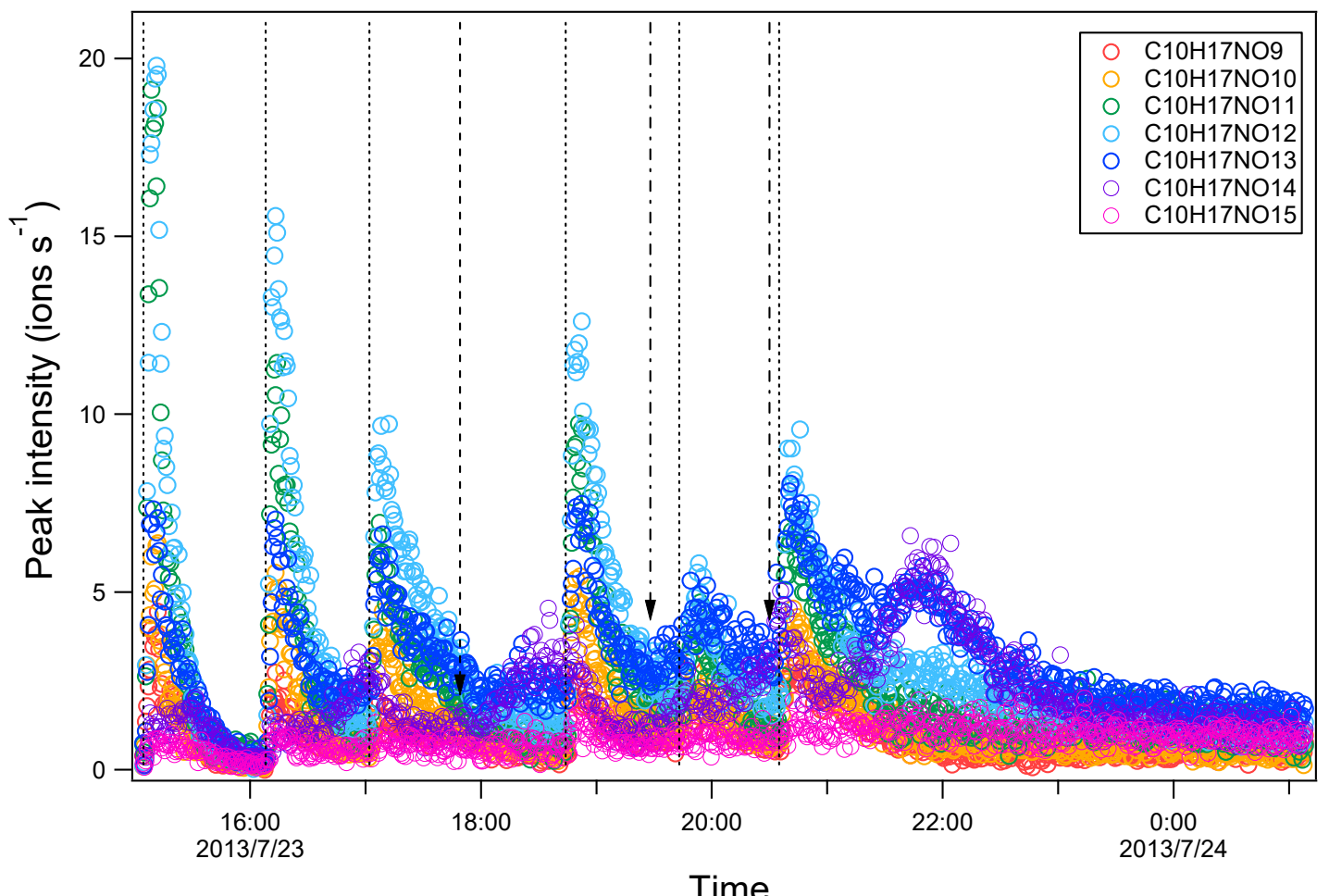

Figure S11. Time series of peak intensity of HOM monomers $\mathrm{C}_{10} \mathrm{H}_{17} \mathrm{NO}_{\mathrm{n}}$ series. The dashed lines indicate the time of isoprene additions. The long-dashed arrow indicates the time of $\mathrm{NO}_{2}$ addition. The dash-dotted arrows indicate the time of $\mathrm{O}_{3}$ additions. 


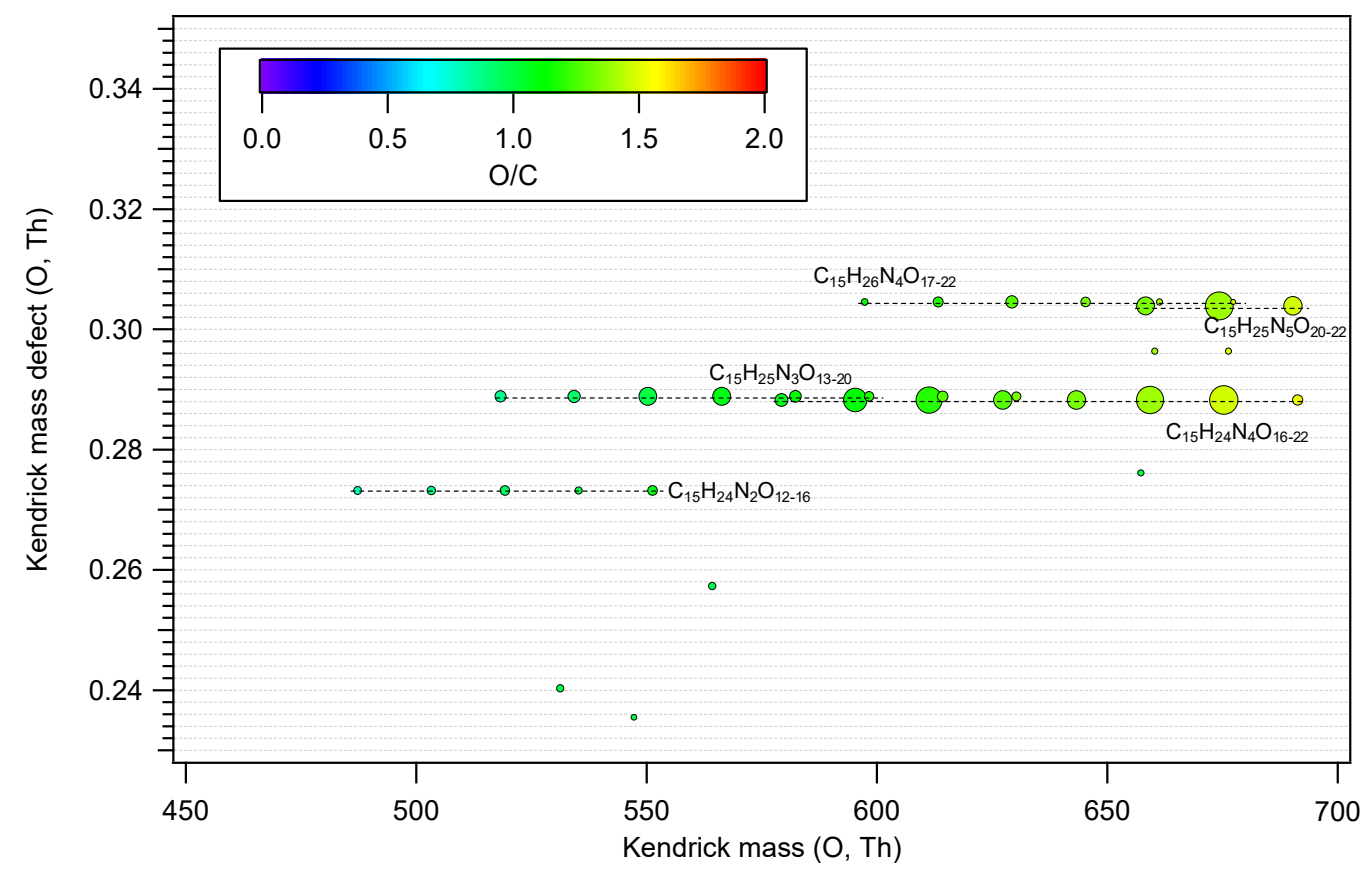

Figure S12. Kendrick mass defect with Kendrick base $\mathrm{O}$ of $\mathrm{HOM}$ trimers formed in isoprene $+\mathrm{NO}_{3}$. The area of the circles is set to be proportional to the average peak intensity of each molecular formula during the first isoprene addition period (P1). 


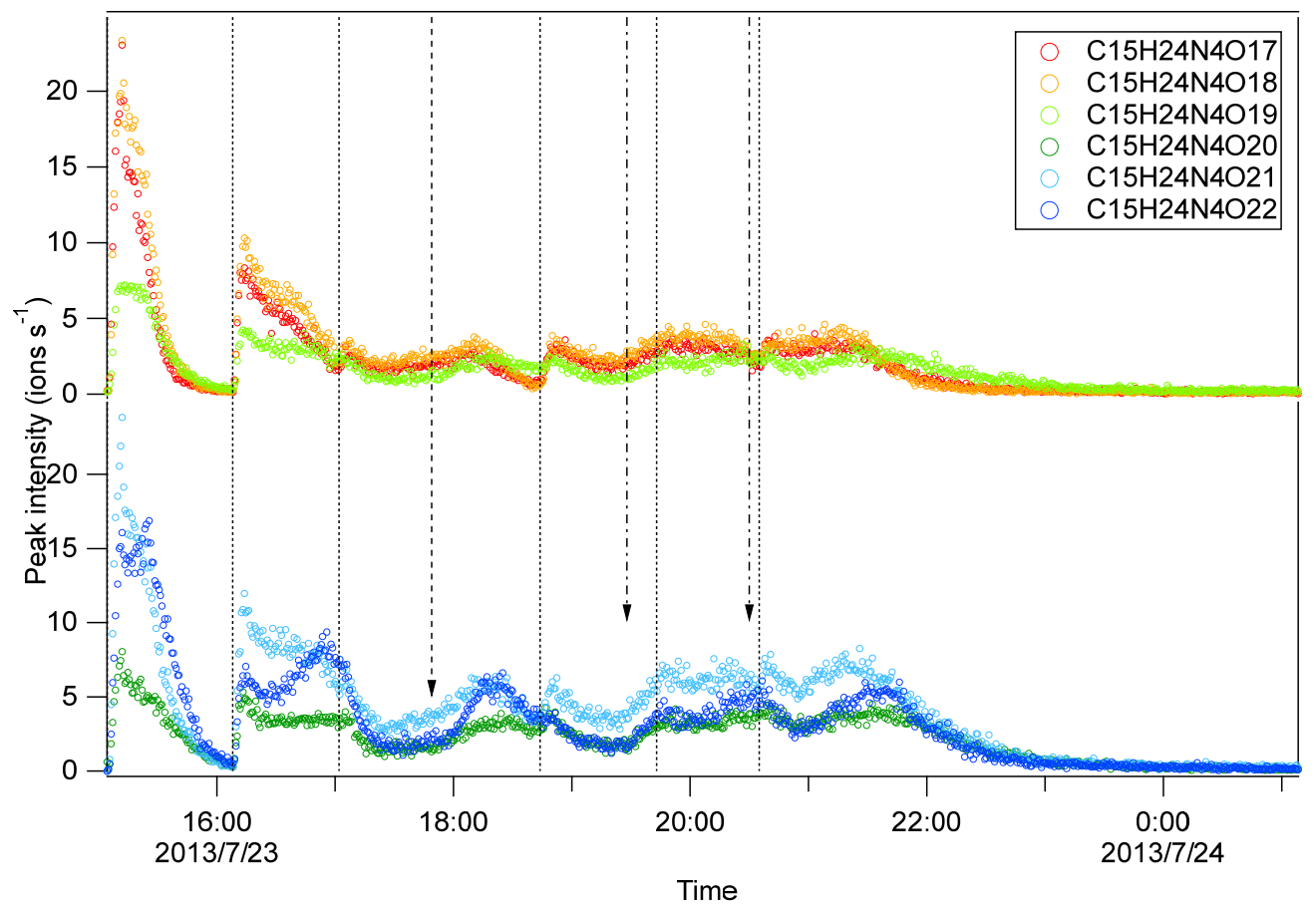

Figure S13. Time series of peak intensity of several HOM dimers of the $\mathrm{C}_{15} \mathrm{H}_{24} \mathrm{~N}_{4} \mathrm{O}_{\mathrm{n}}$ series. It is noted that the compounds are plotted in two panels for clarity. The dashed lines indicate the time of isoprene additions. The long-dashed arrow indicates the time of $\mathrm{NO}_{2}$ addition. The dash-dotted arrows indicate the time of $\mathrm{O}_{3}$ additions. 


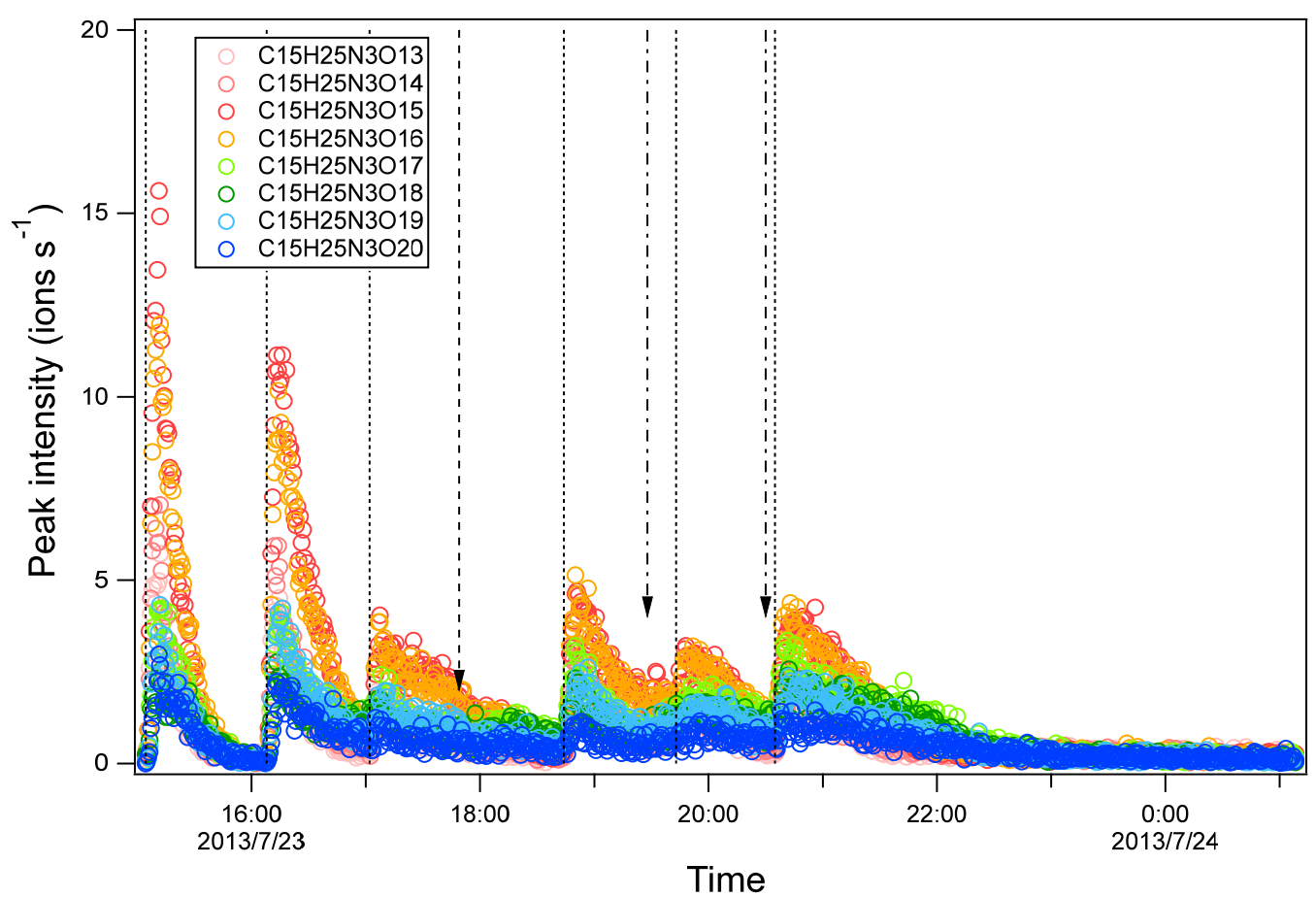

Figure S14. Time series of peak intensity of several HOM dimers of the $\mathrm{C}_{15} \mathrm{H}_{25} \mathrm{~N}_{3} \mathrm{O}_{n}$ series. The dashed lines indicate the time of isoprene additions. The long-dashed arrow indicates the time of $\mathrm{NO}_{2}$ addition. The dash-dotted arrows indicate the time of $\mathrm{O}_{3}$ additions. 


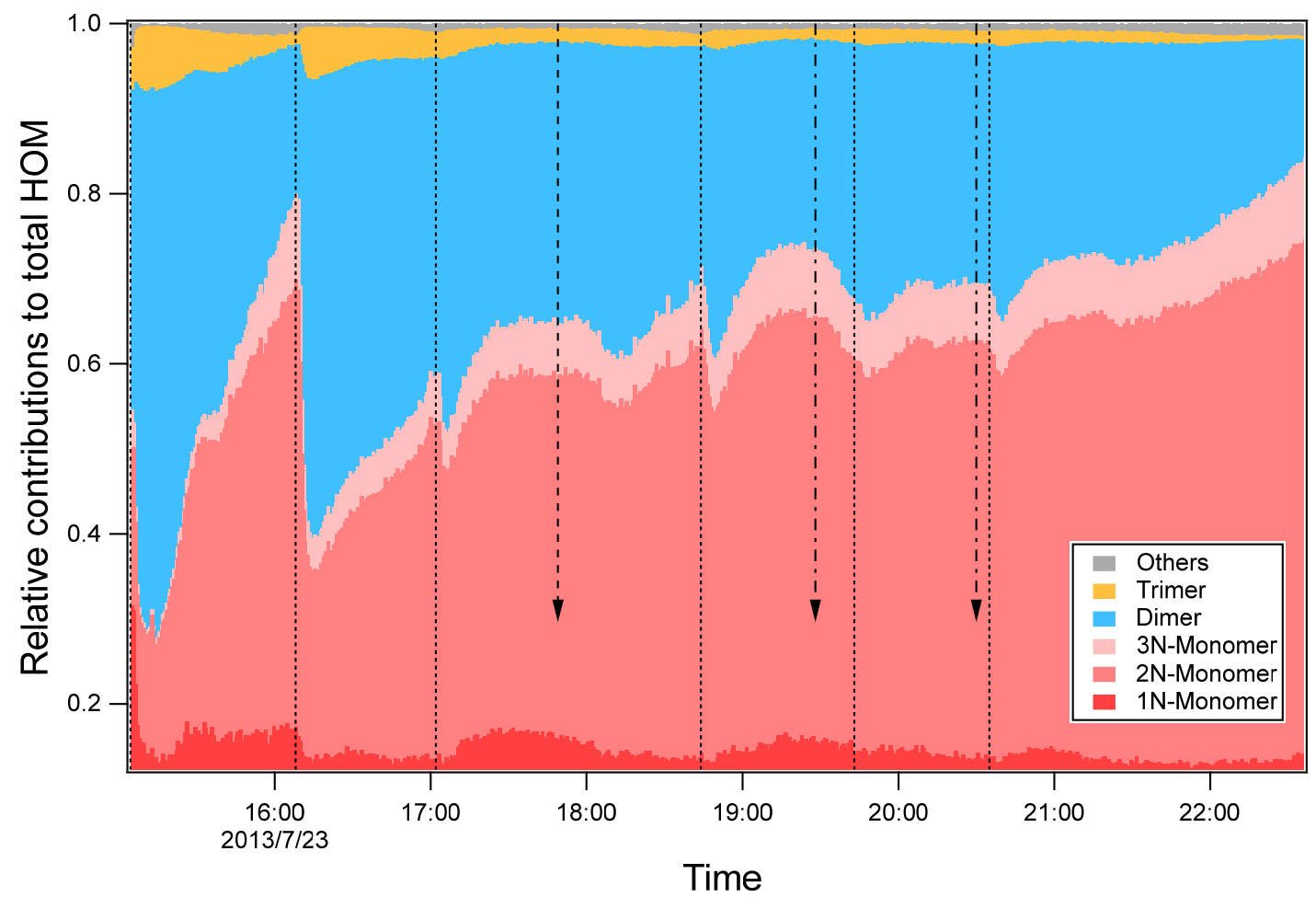

Figure S15. Relative contributions of HOM monomers, dimers, and trimers. Monomer 1-3N refers to the monomers containing 1-3 nitrogen atoms. The dashed lines indicate the time of isoprene additions. The long-dashed arrow indicates the time of $\mathrm{NO}_{2}$ addition. The dash-dotted arrows indicate the time of $\mathrm{O}_{3}$ additions. 
Table S1. Intensity of $\mathrm{HOM}$ monomers $\mathrm{C}_{5} \mathrm{H}_{8} \mathrm{NO}_{n}$ and their corresponding termination products.

\begin{tabular}{|c|c|c|c|c|c|}
\hline Series & Peroxy radical & Carbonyl & Hydroxyl $^{\mathrm{c}}$ & Hydroperoxide $^{c}$ & Carbonyl \\
\hline $\mathbf{m} / \mathbf{z}$ & $\mathbf{m}$ & m-17 & $m-15$ & $m+1$ & /Hydroxyl \\
\hline \multirow{3}{*}{ M1a } & $\mathrm{C}_{5} \mathrm{H}_{8} \mathrm{NO}_{7}$ & $\mathrm{C}_{5} \mathrm{H}_{7} \mathrm{NO}_{6}$ & $\mathrm{C}_{5} \mathrm{H}_{9} \mathrm{NO}_{6}$ & $\mathrm{C}_{5} \mathrm{H}_{9} \mathrm{NO}_{7}$ & \\
\hline & 257.016 & 240.013 & 242.028 & 258.023 & \\
\hline & $1.5 \%{ }^{\mathrm{a}}$ & $4.5 \%$ & $2.5 \%$ & $13.9 \%$ & 1.8 \\
\hline \multirow{3}{*}{ M1b } & $\mathrm{C}_{5} \mathrm{H}_{8} \mathrm{NO}_{8}$ & $\mathrm{C}_{5} \mathrm{H}_{7} \mathrm{NO}_{7}$ & $\mathrm{C}_{5} \mathrm{H}_{9} \mathrm{NO}_{7}$ & $\mathrm{C}_{5} \mathrm{H}_{9} \mathrm{NO}_{8}$ & \\
\hline & 273.010 & 256.008 & 258.023 & 274.018 & \\
\hline & $9.7 \%$ & $8.1 \%$ & $13.9 \%$ & $24.9 \%{ }^{\mathrm{c}}$ & 0.6 \\
\hline \multirow{3}{*}{ M1a } & $\mathrm{C}_{5} \mathrm{H}_{8} \mathrm{NO}_{9}$ & $\mathrm{C}_{5} \mathrm{H}_{7} \mathrm{NO}_{8}$ & $\mathrm{C}_{5} \mathrm{H}_{9} \mathrm{NO}_{8}$ & $\mathrm{C}_{5} \mathrm{H}_{9} \mathrm{NO}_{9}$ & \\
\hline & 289.0053 & 272.0026 & 274.0182 & 290.0131 & \\
\hline & $11.9 \%^{\mathrm{b}}$ & $34.0 \%$ & $24.9 \%$ & $28.5 \%$ & 1.4 \\
\hline \multirow{3}{*}{ M1b } & $\mathrm{C}_{5} \mathrm{H}_{8} \mathrm{NO}_{10}$ & $\mathrm{C}_{5} \mathrm{H}_{7} \mathrm{NO}_{9}$ & $\mathrm{C}_{5} \mathrm{H}_{9} \mathrm{NO}_{9}$ & $\mathrm{C}_{5} \mathrm{H}_{9} \mathrm{NO}_{10}$ & \\
\hline & 305.000 & 287.998 & 290.013 & 306.008 & \\
\hline & $22.2 \%^{\mathrm{b}}$ & $8.3 \%$ & $28.5 \%$ & $5.8 \%$ & 0.3 \\
\hline \multirow{3}{*}{ M1a } & $\mathrm{C}_{5} \mathrm{H}_{8} \mathrm{NO}_{11}$ & $\mathrm{C}_{5} \mathrm{H}_{7} \mathrm{NO}_{10}$ & $\mathrm{C}_{5} \mathrm{H}_{9} \mathrm{NO}_{10}$ & $\mathrm{C}_{5} \mathrm{H}_{9} \mathrm{NO}_{11}$ & \\
\hline & 320.995 & 303.992 & 306.008 & 322.003 & \\
\hline & $2.3 \%$ & $3.0 \%$ & $5.8 \%$ & $2.0 \%$ & 0.5 \\
\hline \multirow{3}{*}{ M1b } & & & $\mathrm{C}_{5} \mathrm{H}_{9} \mathrm{NO}_{11}$ & & \\
\hline & & & 322.003 & & \\
\hline & & & $2.0 \%$ & & \\
\hline
\end{tabular}

${ }^{a}$ : The intensities are average intensity of each peak in MS during the first cycle (C1) normalized to the peak with the maximum intensity $\left(\mathrm{C}_{10} \mathrm{H}_{17} \mathrm{~N}_{3} \mathrm{O}_{13}\right)$.

${ }^{b}$ : These intensities may be subject to higher uncertainties due to the overlap with $\mathrm{C}_{5} \mathrm{H}_{10} \mathrm{~N}_{2} \mathrm{O}_{8}$ and $\mathrm{C}_{5} \mathrm{H}_{10} \mathrm{~N}_{2} \mathrm{O}_{9}$.

c: The relative contribution of HOM with hydroxyl or hydroperoxide cannot be differentiated and thus the total intensity is listed here. 
Table S2. Intensity of $\mathrm{HOM}$ monomers $\mathrm{C}_{5} \mathrm{H}_{9} \mathrm{~N}_{2} \mathrm{O}_{n}$ and their corresponding termination products.

\begin{tabular}{|c|c|c|c|c|c|}
\hline Series & $\begin{array}{l}\text { Peroxy } \\
\text { radical }\end{array}$ & Carbonyl & Hydroxyl & Hydroperoxide & \multirow{2}{*}{$\begin{array}{l}\text { Carbonyl } \\
\text { /Hydroxyl }\end{array}$} \\
\hline $\mathbf{m} / \mathbf{z}$ & $\mathbf{m}$ & m-17 & m-15 & $\mathbf{m}+1$ & \\
\hline \multirow{3}{*}{$\mathrm{M} 2 \mathrm{~b}$} & $\mathrm{C}_{5} \mathrm{H}_{9} \mathrm{~N}_{2} \mathrm{O}_{8}$ & $\mathrm{C}_{5} \mathrm{H}_{8} \mathrm{~N}_{2} \mathrm{O}_{7}$ & & $\mathrm{C}_{5} \mathrm{H}_{10} \mathrm{~N}_{2} \mathrm{O}_{8}$ & \\
\hline & 288.021 & 271.019 & & 289.029 & \\
\hline & $5.6 \%{ }^{\mathrm{a}}$ & $1.3 \%$ & & $99.1 \%$ & 1.6 \\
\hline \multirow{3}{*}{$\mathrm{M} 2 \mathrm{a}$} & $\mathrm{C}_{5} \mathrm{H}_{9} \mathrm{~N}_{2} \mathrm{O}_{9}$ & $\mathrm{C}_{5} \mathrm{H}_{8} \mathrm{~N}_{2} \mathrm{O}_{8}$ & $\mathrm{C}_{5} \mathrm{H}_{10} \mathrm{~N}_{2} \mathrm{O}_{8}$ & $\mathrm{C}_{5} \mathrm{H}_{10} \mathrm{~N}_{2} \mathrm{O}_{9}$ & \\
\hline & 304.0162 & 287.0135 & 289.0291 & 305.024 & \\
\hline & $24.9 \%$ & $57.9 \%$ & $99.1 \%$ & $82.3 \%$ & 0.6 \\
\hline \multirow{3}{*}{$\mathrm{M} 2 \mathrm{~b}$} & $\mathrm{C}_{5} \mathrm{H}_{9} \mathrm{~N}_{2} \mathrm{O}_{10}$ & $\mathrm{C}_{5} \mathrm{H}_{8} \mathrm{~N}_{2} \mathrm{O}_{9}$ & $\mathrm{C}_{5} \mathrm{H}_{10} \mathrm{~N}_{2} \mathrm{O}_{9}$ & $\mathrm{C}_{5} \mathrm{H}_{10} \mathrm{~N}_{2} \mathrm{O}_{10}$ & \\
\hline & 320.011 & 303.008 & 305.024 & 321.019 & \\
\hline & $14.4 \%$ & $29.7 \%$ & $82.3 \%$ & $9.3 \%$ & 0.4 \\
\hline \multirow{3}{*}{$\mathrm{M} 2 \mathrm{a}$} & $\mathrm{C}_{5} \mathrm{H}_{9} \mathrm{~N}_{2} \mathrm{O}_{11}$ & $\mathrm{C}_{5} \mathrm{H}_{8} \mathrm{~N}_{2} \mathrm{O}_{10}$ & $\mathrm{C}_{5} \mathrm{H}_{10} \mathrm{~N}_{2} \mathrm{O}_{10}$ & $\mathrm{C}_{5} \mathrm{H}_{10} \mathrm{~N}_{2} \mathrm{O}_{11}$ & \\
\hline & 336.006 & 319.003 & 321.019 & 337.014 & \\
\hline & $3.3 \%$ & $18.3 \%$ & $9.3 \%$ & $0.4 \%$ & 2.0 \\
\hline \multirow{3}{*}{$\mathrm{M} 2 \mathrm{~b}$} & $\mathrm{C}_{5} \mathrm{H}_{9} \mathrm{~N}_{2} \mathrm{O}_{12}$ & $\mathrm{C}_{5} \mathrm{H}_{8} \mathrm{~N}_{2} \mathrm{O}_{11}$ & $\mathrm{C}_{5} \mathrm{H}_{10} \mathrm{~N}_{2} \mathrm{O}_{11}$ & $\mathrm{C}_{5} \mathrm{H}_{10} \mathrm{~N}_{2} \mathrm{O}_{12}$ & \\
\hline & 352.001 & 334.998 & 337.014 & 353.009 & \\
\hline & $0.7 \%$ & $2.5 \%$ & $0.4 \%$ & $4.3 \%$ & 7.1 \\
\hline
\end{tabular}

a: The intensities are the average intensities of each peak in MS during the first cycle (C1) normalized to the peak with the maximum intensity $\left(\mathrm{C}_{10} \mathrm{H}_{17} \mathrm{~N}_{3} \mathrm{O}_{13}\right)$.

${ }^{b}$ : The relative contribution of HOM with hydroxyl or hydroperoxide cannot be differentiated and thus the total intensity is listed here. 
Table S3. Summary of the 50 major HOM peaks in the reaction of isoprene with $\mathrm{NO}_{3}$

\begin{tabular}{ccc}
$\begin{array}{c}\text { Detected mass } \\
(\mathbf{m} / \mathbf{Q})\end{array}$ & HOM mass (Da) & $\begin{array}{c}\text { HOM } \\
\text { Formula }\end{array}$ \\
\hline 256.008 & 193.022 & $\mathrm{C} 5 \mathrm{H} 7 \mathrm{NO} 7$ \\
258.023 & 195.038 & $\mathrm{C} 5 \mathrm{H} 9 \mathrm{NO} 7$ \\
272.003 & 209.017 & $\mathrm{C} 5 \mathrm{H} 7 \mathrm{NO} 8$ \\
273.010 & 210.025 & $\mathrm{C} 5 \mathrm{H} 8 \mathrm{NO} 8$ \\
274.018 & 211.033 & $\mathrm{C} 5 \mathrm{H} 9 \mathrm{NO} 8$ \\
287.013 & 224.028 & $\mathrm{C} 5 \mathrm{H} 8 \mathrm{~N} 2 \mathrm{O} 8$ \\
287.997 & 225.012 & $\mathrm{C} 5 \mathrm{H} 7 \mathrm{NO} 9$ \\
289.005 & 226.020 & $\mathrm{C} 5 \mathrm{H} 8 \mathrm{NO} 9$ \\
289.029 & 226.044 & $\mathrm{C} 5 \mathrm{H} 10 \mathrm{~N} 2 \mathrm{O} 8$ \\
290.013 & 227.028 & $\mathrm{C} 5 \mathrm{H} 9 \mathrm{NO} 9$ \\
303.008 & 240.023 & $\mathrm{C} 5 \mathrm{H} 8 \mathrm{~N} 2 \mathrm{O} 9$ \\
304.016 & 241.031 & $\mathrm{C} 5 \mathrm{H} 9 \mathrm{~N} 2 \mathrm{O} 9$ \\
305.000 & 242.015 & $\mathrm{C} 5 \mathrm{H} 8 \mathrm{NO} 10$ \\
305.024 & 242.039 & $\mathrm{C} 5 \mathrm{H} 10 \mathrm{~N} 2 \mathrm{O} 9$ \\
306.008 & 243.023 & $\mathrm{C} 5 \mathrm{H} 9 \mathrm{NO} 10$ \\
318.019 & 255.034 & $\mathrm{C} 5 \mathrm{H} 9 \mathrm{~N} 3 \mathrm{O} 9$ \\
319.003 & 256.018 & $\mathrm{C} 5 \mathrm{H} 8 \mathrm{~N} 2 \mathrm{O} 10$ \\
320.011 & 257.026 & $\mathrm{C} 5 \mathrm{H} 9 \mathrm{~N} 2 \mathrm{O} 10$ \\
321.019 & 258.034 & $\mathrm{C} 5 \mathrm{H} 10 \mathrm{~N} 2 \mathrm{O} 10$ \\
334.014 & 271.029 & $\mathrm{C} 5 \mathrm{H} 9 \mathrm{~N} 3 \mathrm{O} 10$ \\
351.006 & 224.028 & $\mathrm{C} 5 \mathrm{H} 8 \mathrm{~N} 2 \mathrm{O} 8$ \\
353.022 & 226.044 & $\mathrm{C} 5 \mathrm{H} 10 \mathrm{~N} 2 \mathrm{O} 8$ \\
367.001 & 240.023 & $\mathrm{C} 5 \mathrm{H} 8 \mathrm{~N} 2 \mathrm{O} 9$ \\
368.009 & 241.031 & $\mathrm{C} 5 \mathrm{H} 9 \mathrm{~N} 2 \mathrm{O} 9$ \\
369.017 & 242.039 & $\mathrm{C} 5 \mathrm{H} 10 \mathrm{~N} 2 \mathrm{O} 9$ \\
372.055 & 309.070 & $\mathrm{C} 10 \mathrm{H} 15 \mathrm{NO} 10$ \\
403.061 & 340.075 & $\mathrm{C} 10 \mathrm{H} 16 \mathrm{~N} 2 \mathrm{O} 11$ \\
405.076 & 342.091 & $\mathrm{C} 10 \mathrm{H} 18 \mathrm{~N} 2 \mathrm{O} 11$ \\
419.056 & 356.070 & $\mathrm{C} 10 \mathrm{H} 16 \mathrm{~N} 2 \mathrm{O} 12$ \\
434.067 & 371.081 & $\mathrm{C} 10 \mathrm{H} 17 \mathrm{~N} 3 \mathrm{O} 12$ \\
434.067 & 371.081 & $\mathrm{C} 10 \mathrm{H} 17 \mathrm{~N} 3 \mathrm{O} 12$ \\
435.051 & 372.065 & $\mathrm{C} 10 \mathrm{H} 16 \mathrm{~N} 2 \mathrm{O} 13$ \\
450.062 & 387.076 & $\mathrm{C} 10 \mathrm{H} 17 \mathrm{~N} 3 \mathrm{O} 13$ \\
451.046 & 388.060 & $\mathrm{C} 10 \mathrm{H} 16 \mathrm{~N} 2 \mathrm{O} 14$ \\
464.041 & 401.055 & $\mathrm{C} 10 \mathrm{H} 15 \mathrm{~N} 3 \mathrm{O} 14$ \\
466.056 & 403.071 & $\mathrm{C} 10 \mathrm{H} 17 \mathrm{~N} 3 \mathrm{O} 14$ \\
467.040 & 404.055 & $\mathrm{C} 10 \mathrm{H} 16 \mathrm{~N} 2 \mathrm{O} 15$ \\
482.051 & 419.066 & $\mathrm{C} 10 \mathrm{H} 17 \mathrm{~N} 3 \mathrm{O} 15$ \\
498.046 & 435.061 & $\mathrm{C} 10 \mathrm{H} 17 \mathrm{~N} 3 \mathrm{O} 16$ \\
498.059 & 371.081 & $\mathrm{C} 10 \mathrm{H} 17 \mathrm{~N} 3 \mathrm{O} 12$ \\
499.030 & 436.045 & $\mathrm{C} 10 \mathrm{H} 16 \mathrm{~N} 2 \mathrm{O} 17$ \\
513.057 & 450.072 & $\mathrm{C} 10 \mathrm{H} 18 \mathrm{~N} 4 \mathrm{O} 16$ \\
& 451.056 & $\mathrm{C} 10 \mathrm{H} 17 \mathrm{~N} 3 \mathrm{O} 17$ \\
& 387.076 & $\mathrm{C} 10 \mathrm{H} 13 \mathrm{~N} 3 \mathrm{O} 13$ \\
$\mathrm{C} 14054$ & & \\
\hline & 466.067 & $\mathrm{H} 18 \mathrm{~N} 4 \mathrm{O} 17$ \\
& &
\end{tabular}




\begin{tabular}{lll}
530.036 & 467.051 & $\mathrm{C} 10 \mathrm{H} 17 \mathrm{~N} 3 \mathrm{O} 18$ \\
611.094 & 548.109 & $\mathrm{C} 15 \mathrm{H} 24 \mathrm{~N} 4 \mathrm{O} 18$ \\
659.079 & 596.093 & $\mathrm{C} 15 \mathrm{H} 24 \mathrm{~N} 4 \mathrm{O} 21$ \\
674.090 & 611.104 & $\mathrm{C} 15 \mathrm{H} 25 \mathrm{~N} 5 \mathrm{O} 21$ \\
675.074 & 612.088 & $\mathrm{C} 15 \mathrm{H} 24 \mathrm{~N} 4 \mathrm{O} 22$ \\
\hline
\end{tabular}

